\title{
Design of Photovoltaic Systems Using Computer Software
}

\author{
Paweł Kut ${ }^{1 *}$, Krzysztof Nowak ${ }^{1}$ \\ ${ }^{1}$ Rzeszow University of Technology, Department of Heat Engineering and Air Conditioning, \\ Al. Powstańców Warszawy 6, 35-959 Rzeszów, Poland \\ * Corresponding author's e-mail: p.kut@prz.edu.pl
}

\begin{abstract}
Renewable energy sources such as solar, wind and hydroelectric power plants are an inexhaustible and clean source of electricity and heat. The development of civilization, resulting in a constant increase in the demand for electricity and the prospect of fossil fuels depletion, including coal and oil, forces us to seek new sources of energy and invest in the renewable energy sources. The development of technology and the policy of the European Union have a positive impact on the development of renewable energy sources and the increase in the installed capacity. One of the ways of obtaining electricity from renewable sources is through the photovoltaic cells. Computer software is becoming helpful in designing the photovoltaic installations. Simulations enable conducting the economic analysis and selection of the best possible installation parameters. This enables the best use of the available conditions to obtain the largest production of electricity. The article presents a project of a photovoltaic installation for a single-family building using the BlueSol Design software.
\end{abstract}

Keywords: photovoltaic, computer simulation, solar energy

\section{INTRODUCTION}

Nowadays, electricity is necessary for the proper functioning of civilization and society. The constant increase in the demand for electricity, which is a consequence of the technological development, requires the construction of new energy sources that will satisfy the growing demand. Coal, gas or other fossil fuels power plants, which are the source of air pollution [Nowak 2017], must be gradually replaced with the renewable energy sources such as wind, solar or biomass power plants. According to the data of the Polish National Energy Conservation Agency, the electricity consumption in Poland will increase from 165.8 TWh in 2017 to 230 TWh in 2040 [Polish National Energy Conservation Agency 2018]. In this report, the share of renewable energy in the national energy mix is expected to increase to $33 \%$. To a large extent, the photovoltaic installations may be able to cover the growing demand for electricity.
In recent years, a large increase in the installed capacity of photovoltaic installations can be observed [Sward 2019]. Figure 1 shows the increase in the installed capacity in Europe since 2005. The development of technology and the related decline in the prices of such installations, the European Union policy to increase the share of the renewable energy sources in the energy production and financial support systems, favour the development of distributed energy sources, including the photovoltaic installations.

Computer software is very helpful in the photovoltaic installation design, economic analysis and preliminary analysis of the profitability of investment. It enables to predict at the design stage the electricity generation based on meteorological data for a given location from previous years. The paper presents an analysis of a photovoltaic installation designed for a real building located in Poland in the Podkarpackie voivodeship based on the actual electricity consumption of a single-family building with the use of the BlueSol Design software. 


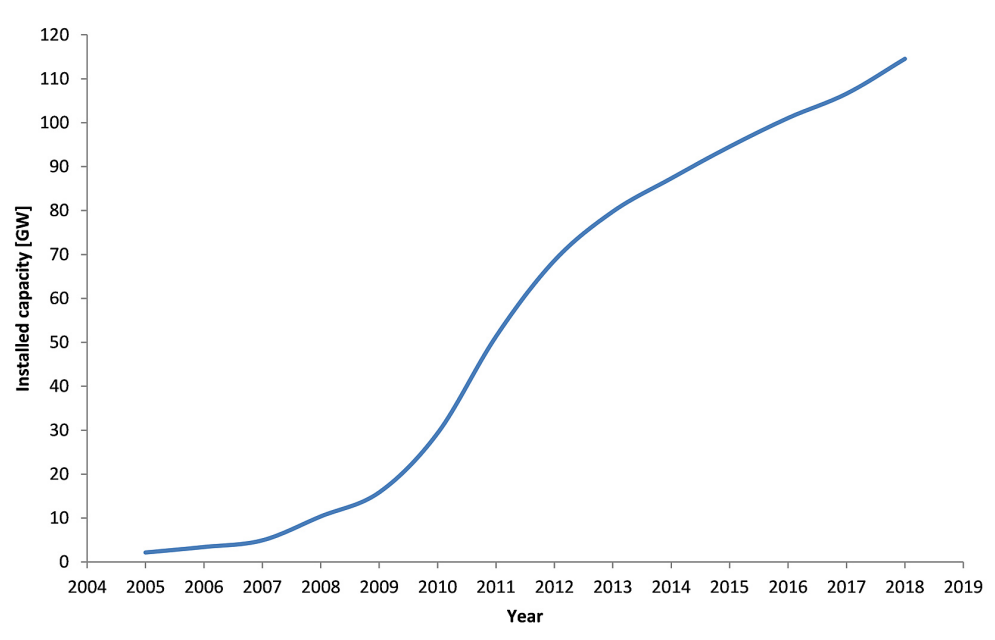

Figure 1. Installed capacity in the photovoltaic installations in Europe according to the Eurostat data [Eurostat 2019]

\section{TYPES OF SOLAR CELLS}

Photovoltaic cells can be divided into three generations [Klugmann-Radziemska 2014]. The first-generation cells are based on a traditional p-n silicon junction [Bagher 2015, Luceño-Sánchez 2019]. They are made of pure crystalline silicon as wafers with a thickness of 200-300 $\mu \mathrm{m}$. They have an efficiency of $17-22 \%$ and high production costs due to the high cost of silicon. Among the first generation cells, the monocrystalline, polycrystalline and amorphous cells can be distinguished. The monocrystalline cells are made of a single silicon crystal with an ordered structure. The monocrystalline cells have an efficiency of $18-22 \%$. In order to manufacture a monocrystalline cell, it is necessary to produce single silicon crystals. The Czochralski process, which involves pulling a single crystal from the molten mass of polycrystals, is most often used for this purpose. The polycrystalline cells are another type of the 1 st generation photovoltaic cells. They are made of silicon wafers arranged irregularly in relation to their crystal structure. Due to the lower production costs, polycrystalline cells are cheaper than the monocrystalline cells; however, they have a lower efficiency, amounting to $15-18 \%$. The amorphous cells are made of amorphous, noncrystallized silicon and have a very low efficiency of $6-10 \%$ offset by a low price.

The second generation cells, like the first generation cells, are built based on the $\mathrm{p}-\mathrm{n}$ connector [Badawy 2015]. However, e.g. cadmium telluride, a mixture of copper, gallium, indium, selenium or amorphous silicon are used for their production, rather than crystalline silicon. The second generation cells have a very thin semiconductor layer of $1-3 \mu \mathrm{m}$. The disadvantage of this type of cells is relatively low efficiency, which is about $7-15 \%$.

One type of the second generation cell is a cell made of amorphous silicon [Qarony 2017]. The production costs of these cells are low due to the low temperature production process and the small amount of material needed to produce the cells. The cell production consists of applying thin layers of silicon to a material that can be glass, plastic or steel. The cells made of cadmium telluride constitute another type. Cadmium is one of the most toxic elements. This is a serious problem when recycling the cells. Due to the small amount of tellurium present on Earth, the development of this type of cell may be limited. Another type of the second generation cells are the CIS/CIGS cells - made of copper-indium selenium and copper-indium-gallium selenide. These elements form a material with high light absorption. The CIS/CIGS cell efficiency ranges from 11 to $15 \%$. The cells made of gallium arsenide (GaAs) constitute another type. The gallium arsenide cells are one of the most efficient cells, their efficiency reaches up to $30 \%$. However, due to the high price and high toxicity of chemical reagents, the gallium arsenide cells are mainly used to power space probes.

The third generation photovoltaic cells do not have a p-n connector, which is necessary for the first and second generation cells. The materials used to manufacture the cells are cheap, easily available and non-toxic. These links can be used as translucent windows, covering tents and clothes. The dye cells are one of the technologies 
of the third generation of photovoltaic cells [Fitra 2013]. These are devices the mechanism of action of which is similar to the process of photosynthesis. The cell consists of two electrodes, which are separated by a liquid or solid electrolyte. Sunlight is absorbed by dye molecules in which the electron goes into the excited state. Then the electron is transported from the excited state of the dye to the semiconductor conductivity band, where the electron reaches the semiconductive glass. Then, the external circuit, the load is transported to the counter electrode. The charge path ends with the reduction of the excited state of the dye molecule by means of an electron from the cathode, transported by a redox pair found in the electrolyte. For the cells available on the market, the efficiency is about $10 \%$. Organic cells constitue another type of third generation photovoltaic cells [Yeh 2013]. In organic cells, energy conversion is carried out using low-molecular organic molecules and electroactive polymers. In the cells, solar radiation is absorbed by the donor layer (material transporting a positive charge), which creates an electronhole pair that diffuses into the phase boundary of two materials, where dissociation into free charge carriers occurs. Then, the electrons move to the negative electrode and the holes to the positive electrode. The result is an electrical voltage between two electrodes.

\section{OVERVIEW OF AVAILABLE SOFTWARE FOR DESIGNING PHOTOVOLTAIC INSTALLATIONS}

The program used for the analysis in this article is Bluesol Design. This program enables detailed modelling of terrestrial and roof photovoltaic systems. It enables calculation of voltage drops on installation cables, control of electrical components, 3D visualization of the designed object, shading simulation, selection of elements such as photovoltaic panels or an inverter from the database. An economic analysis can also be carried out with this program.

PVSol is another simulation software for PV installations. The program also allows the simulation of ground and roof installations. The program enables simulations of shadows caused by such objects as chimneys, trees or other buildings. PVSol also enables a 3D visualization of the designed object.
Solarius-PV is another piece of software. It is BIM software for the photovoltaic system design, which enables installation design and conducting a financial analysis.

The PVCAD program is also used to design the PV installations. The program is used to calculate, analyze and optimize the elements of solar installations. The program has a rich library of solar panels and inverters. The program also allows a $3 \mathrm{D}$ visualization of the designed building and conducting a financial analysis.

It is also possible to use freeware programs for the design of PV installations. One of them is SMA Sunny Design. The program is used to design, dimension and simulate the operation of solar installations. The program is semi-open, i.e. the user must use SMA products in the project, such as inverters, battery charge controllers, etc.).

\section{PHOTOVOLTAIC INSTALLATION DESIGN AND SIMULATION FOR A SINGLE-FAMILY HOUSE}

The analyzed single-family building is located in Poland in Strzyżów, in the Podkarpackie voivodeship. Fig. 2 shows the average monthly insolation for a given location. On the basis of this data, the program calculates the electricity yield per year.

The actual annual energy consumption for the analyzed building is $1692 \mathrm{kWh}$ (data based on bills from the energy supplier). The annual cost of electricity is 261.82 euro. Relatively low energy consumption results from the fact of heating the building and the preparation of domestic hot water using a coal-fired furnace.

Figure 3 and figure 4 shows a model of designed building made by using BlueSol software.

Considering the electricity consumption, a photovoltaic system to cover the annual demand for electricity has been designed. An installation consisting of $7300 \mathrm{~W}$ monocrystalline panels connected in series with a total power of $2.1 \mathrm{~kW}$ was designed, which will be connected through a two-way electricity meter to the distribution network. This will allow the electricity to be sent in two directions, i.e. when solar panels will not produce enough energy, e.g. at night or on cloudy days, electricity will be drawn from the grid. In the case of greater energy production than the current demand, energy will be sold to the grid. 


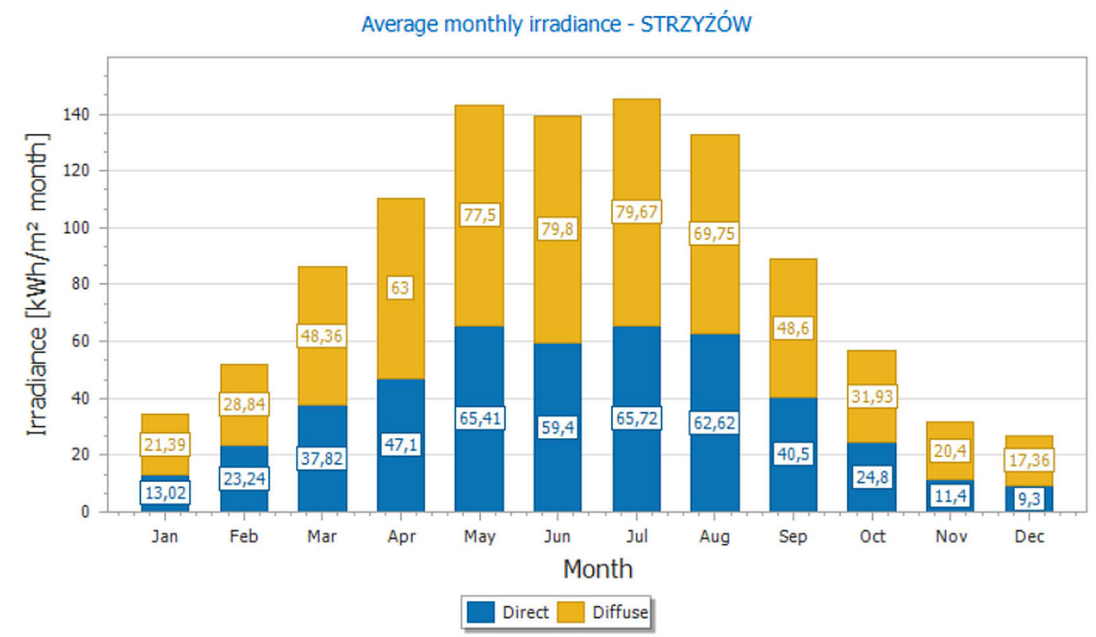

Figure 2. Average monthly radiation for Strzyżów

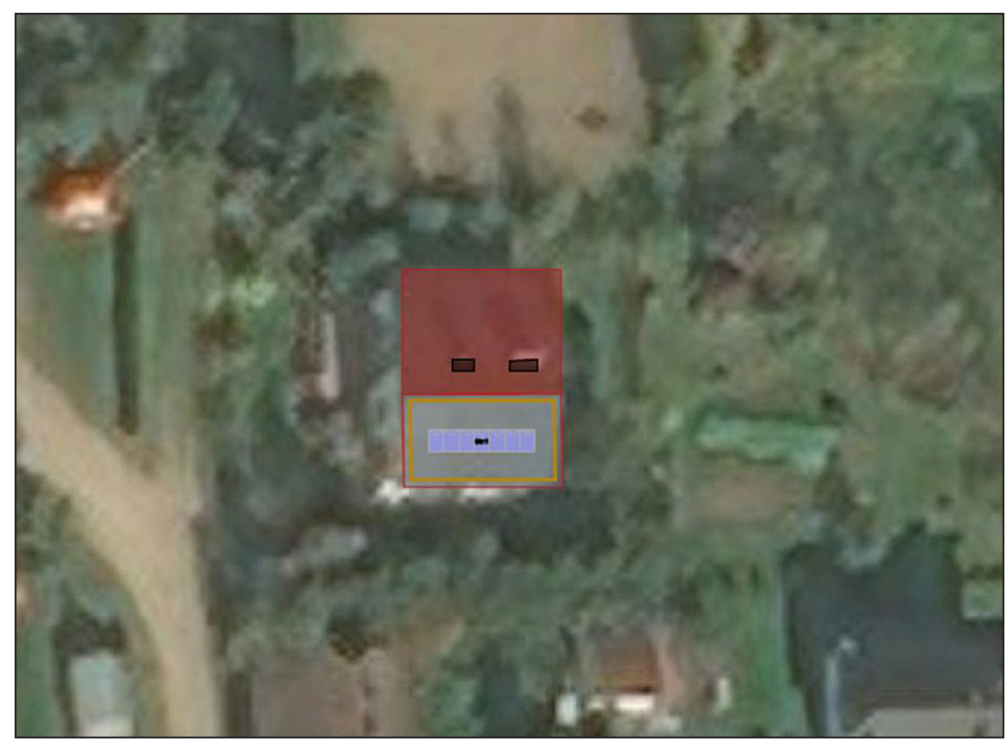

Figure 3. Top view of the analyzed building

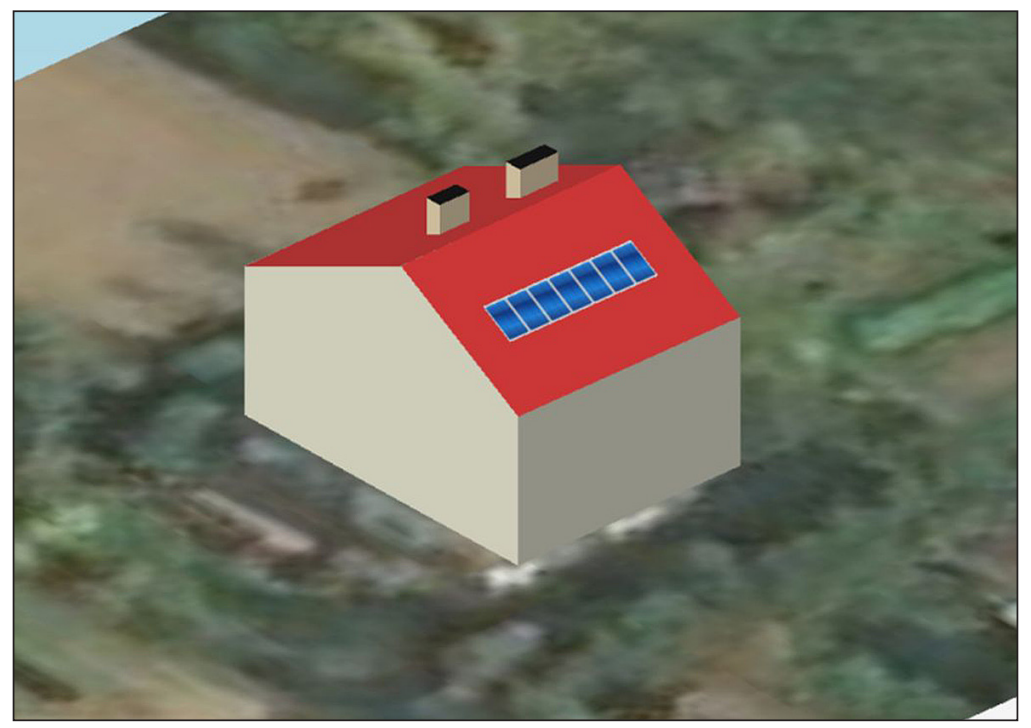

Figure 4. 3D model of the analyzed building 
BlueSol also allows conducting a detailed simulation of shading by chimneys, adjacent trees or buildings. Figure 5 shows an example of shading simulation for December 23 at 13:00 and the figure 6 shows path of the sun along with the azimuth of the building.

Figure 7 shows the electric diagram of the designed installation. The SMA Solar Technology AG SB 2000HF-30 inverter was selected for installation.

Energy losses will occur in the analyzed solar system. On the basis of calculations performed in the BlueSol software, the energy losses in the system will be $15 \%$. The losses will occur in the system are as follows:

- mismatch losses $-2 \%$;
- resistive losses $-4 \%$;

- losses due to DC / AC conversion - 5\%;

- heat loss - 3\%;

- other losses - $1 \%$.

Table 1 presents basic data regarding the designed photovoltaic installation.

Figure 8 shows the electricity production in individual months. It can be seen that there will be surplus energy in summer and that the energy produced in winter will be too low to cover the demand.

Photovoltaic panels are characterized by a decrease in power during installation. In the case of the panels selected for the analyzed installation, the manufacturer declares a $17 \%$ decrease in efficiency over 25 years. Figure 9 shows the

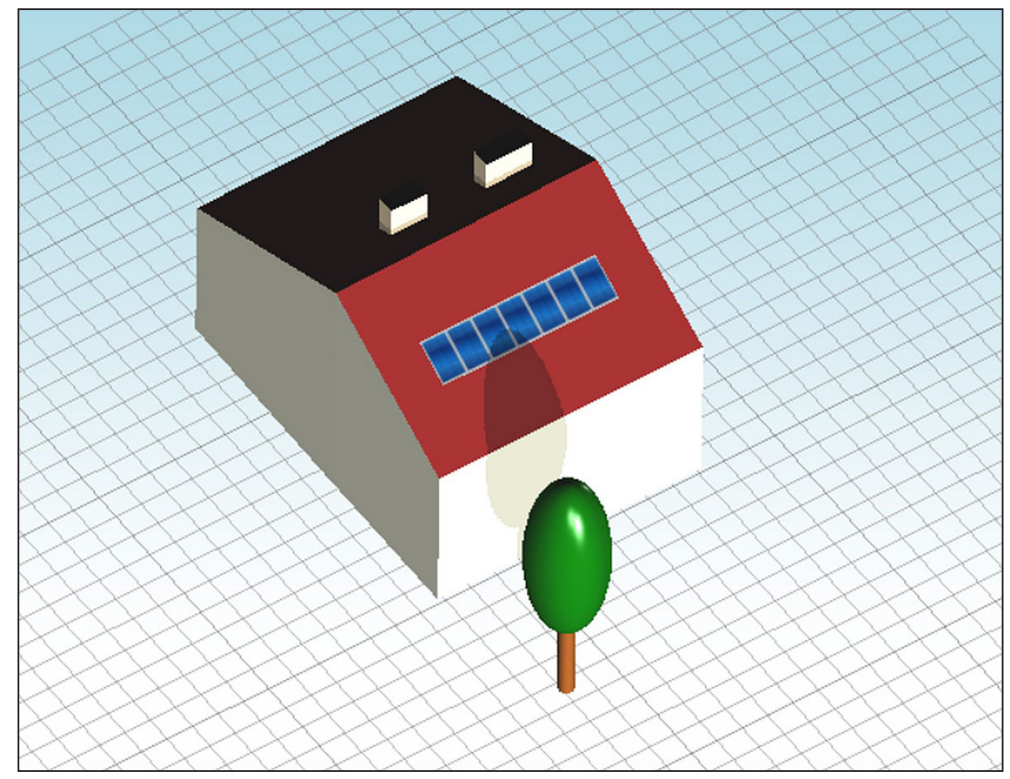

Figure 5. Shading simulation in the BlueSol software

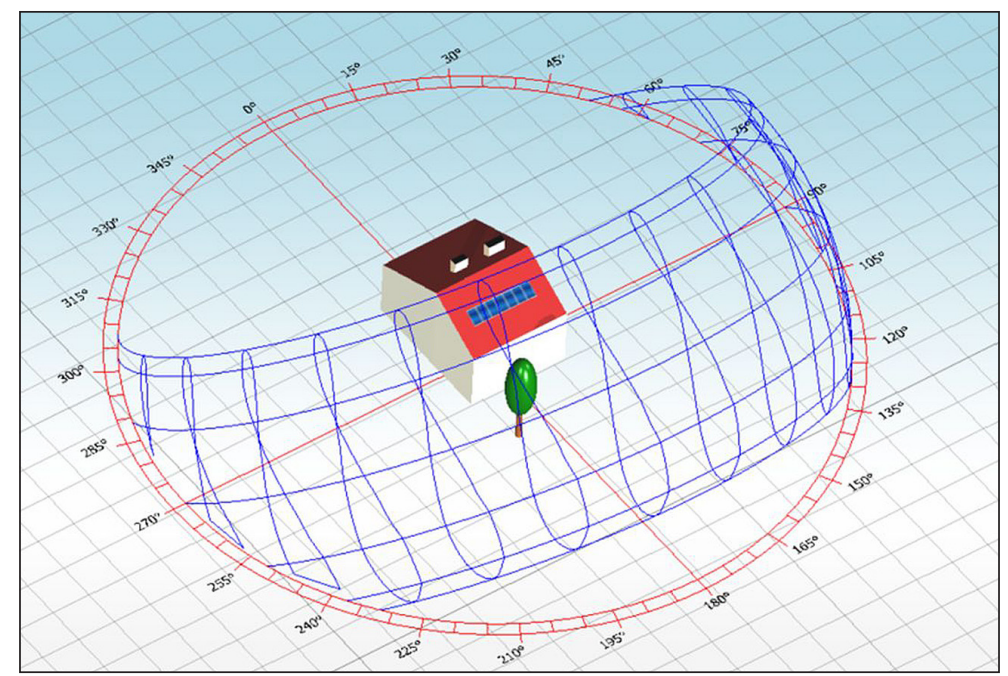

Figure 6. Path of the Sun 


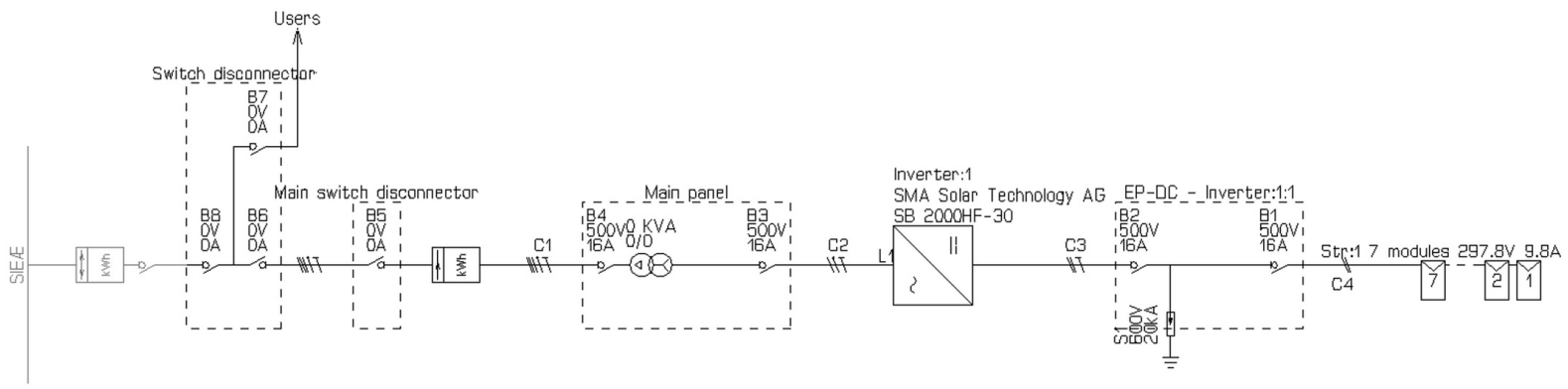

Figure 7. Electrical diagram of the installation

Table 1. Photovoltaic system specification

\begin{tabular}{|l|c|}
\hline Rated power & $2,1 \mathrm{kWp}$ \\
\hline Number of modules & 7 \\
\hline Modules area & $11,41 \mathrm{~m}^{2}$ \\
\hline DC maximum voltage & $297,78 \mathrm{~V}$ \\
\hline DC maximum current & $9,85 \mathrm{~A}$ \\
\hline Maximum MPPT voltage & $253,68 \mathrm{~V}$ \\
\hline Minimum MPPT voltage & $196,95 \mathrm{~V}$ \\
\hline Annual energy production & $2111,89 \mathrm{kWh}$ \\
\hline Annual productivity & $1005,66 \mathrm{kWh} / \mathrm{kWp}$ \\
\hline Annual $\mathrm{CO}_{2}$ reduction & $1267,13 \mathrm{~kg}$ \\
\hline
\end{tabular}

decrease in annual energy production during 25 years of operation.

It can be seen that assuming similar climatic conditions over 25 years, the electricity production will decrease by $327.65 \mathrm{kWh}$ and will be $1,784.24 \mathrm{kWh}$ after 25 years, which is $84.48 \%$ of energy production in the first year $(2111.89 \mathrm{kWh})$. The decrease in the amount of energy produced in subsequent years of operation results in an increase in the time needed for return on investment.

\section{CONCLUSION}

Computer simulations allow a detailed analysis of the designed installation, so that the yield of electricity can be predicted at the design stage. The simulations also enable conducting a shading analysis, which can be particularly important for buildings adjacent to tall buildings. The shading simulation can also help position panels on the roof to minimize chimney shading.

In the analyzed case, the annual energy production in the first year of use, calculated on the basis of climate data from previous years, will be $2111.89 \mathrm{kWh}$. The planned installation is not equipped with batteries, but with a bi-directional electric meter, enabling the transmission of energy in both directions. As a result, the energy produced by the installation during the day will be fed into the grid. Owing to the system in force in Poland, a prosumer can use the energy produced by drawing it from the network, if the installation does not produce enough energy, e.g. at night. Settlement with the energy company takes place at the end of the settlement period.

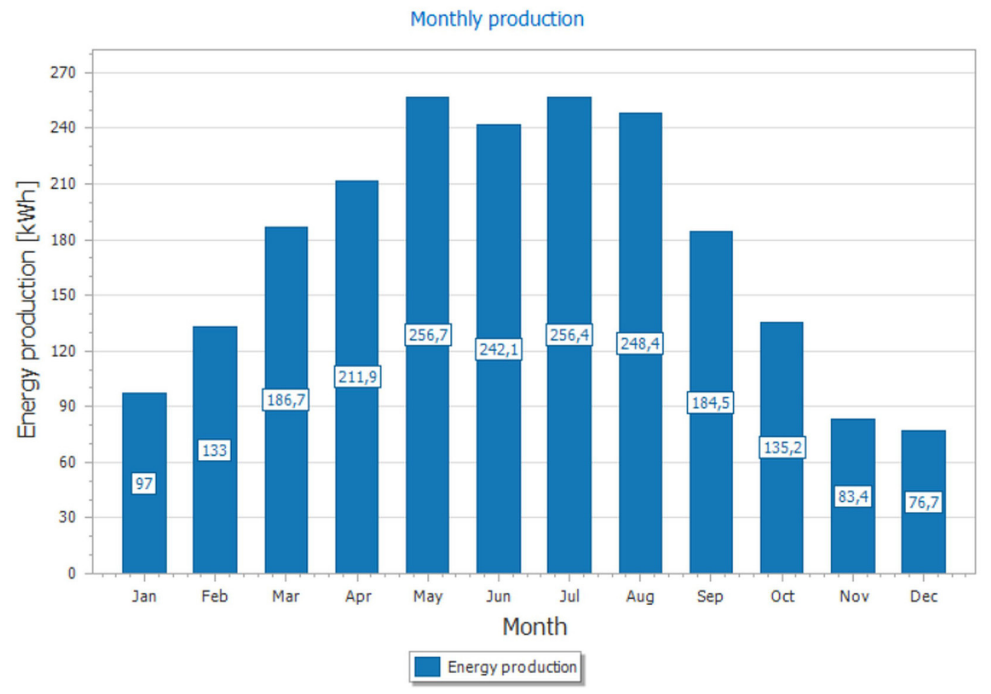

Figure 8. Monthly electricity production 


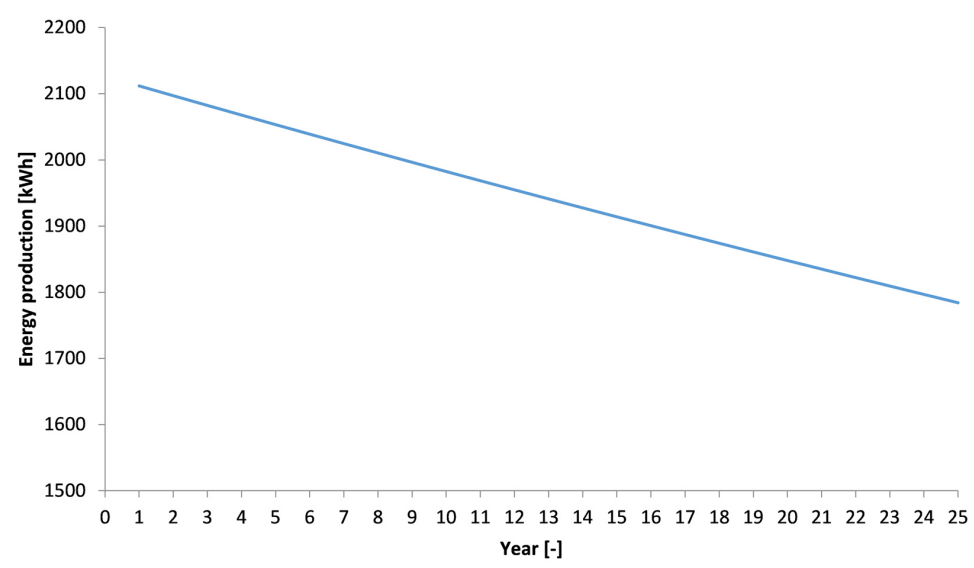

Figure 9. Decline in energy production over 25 years

\section{REFERENCES}

1. Bagher A.M., Vahid M.M.A., Mohsen M. 2015. Types of Solar Cells and Application. American Journal of Optics and Photonics, 3(5), 94-113

2. Badawy W.A. 2015. A review on solar cells from Si-single crystals to porous materials and quantum dots. Journal of Advanced Research, 6, 123-132

3. Fitra M., Daut I., Gomesh N., Irwanto M., Irwan Y. M. 2013. Dye Solar Cell Using Syzigium Oleina Organic Dye. Energy Procedia, 36, 341-348

4. https://ec.europa.eu/

5. Klugmann-Radziemska E. 2014. Technologiczny postęp w fotowoltaice. Czysta Energia, 5, 40-42

6. Luceño-Sánchez J.A., Díez-Pascual A.M., Peña Capilla R. 2019. Materials for Photovoltaics: State of Art and Recent Developments. Internation Journal of Molecular Sciences, 20, 1-42

7. Nowak K., Bukowska M., Proszak-Miąsik D., Rabczak S. 2017. Emission of Air Pollutants in the Hot Water Production. Iop Conf Ser-Mat Sci., 245

8. Polish National Energy Conservation Agency data

9. Qarony W., Hossain M.I., Hossain M.K., Uddin M. J., Haque A., Saad A.R., Tsang Y.H. 2017. Efficient amorphous silicon solar cells: characterization, optimization, and optical loss analysis. Results in Physics, 6, 4287-4293

10. Sward J.A., Siff J., Gu J., Zhang K.M. 2019. Strategic planning for utility-scale solar photovoltaic development - Historical peak events revisited. Applied Energy, 250, 1292-1301

11. Yeh N., Yeh P. 2013. Organic solar cells: Their developments and potentials. Renewable and Sustainable Energy Reviews, 21, 421-431 